\title{
Analysis of Serum Cholesterol, Statins and Atherosclerotic Plaque in Ruptured and Unruptured Intracranial Aneurysm
}

\section{Análise de colesterol sérico, estatina e placa aterosclerótica em aneurisma intracraniano roto e não roto}

\author{
Leonardo Zumerkorn Pipek ${ }^{1}$ Nícollas Nunes Rabelo ${ }^{2}$ Henrique Zumerkorn Pipek ${ }^{3}$ (i) \\ Joao Paulo Mota Telles ${ }^{10}$ Natalia Camargo Barbat ${ }^{1}$ (1) Antônio Carlos Samaia da Silva Coelho ${ }^{10}$

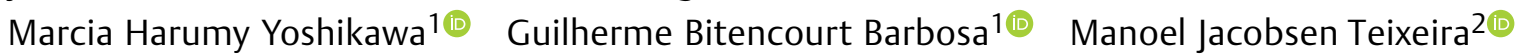 \\ Eberval Gadelha Figueiredo ${ }^{20}$
}

1 Faculdade de Medicina FMUSP, Universidade de São Paulo, São Paulo, SP, Brazil.

2 Department of Neurosurgery, Universidade de São Paulo, São Paulo, SP, Brazil.

${ }^{3}$ School of Medical Sciences, Santa Casa de São Paulo, São Paulo, SP, Brazil.

\begin{abstract}
Address for correspondence Nícollas Nunes Rabelo, MD, Division of Neurosurgery, School of Medicine-Universidade de São Paulo (FMUSP), São Paulo - SP, Brasil. Hospital das Clínicas / FMUSP - Rua Dr. Enéas de Carvalho Aguiar, 255-05403-010-28 São Paulo, SP - Brasil (e-mail: nicollasrabelo@hotmail.com).
\end{abstract}

\begin{abstract}
Keywords

- cholesterol

- statins

- plaques

- outcomes for IA

Introduction Intracranial aneurysm (IA) is a major healthcare concern. The use of statin to reduce serum cholesterol has shown evidence to reduce cardiovascular risk in various diseases, but the impact on IA has not been described. This study aims to determine whether statin use, and serum cholesterol levels interfere with outcomes after IA event. Methods A cohort of patients with IA was analyzed. Patients social and demographics data were collected. Modified Rankin scale (mRS) score after 6 months of follow-up was the endpoint. The data regarding statins use, presence or not of atherosclerotic plaque in radiological images and serum cholesterol of 35 patients were included in our study. Linear regression models were used to determine the influence of those 6 variables in the clinical outcome.

Results The prevalence of atherosclerotic plaque, high cholesterol and use of statins was $34.3 \%, 48.5 \%$, and $14.2 \%$, respectively. Statins and serum cholesterol did not impact the overall outcome, measured by mRS after 6 months $(p>0.05)$, but did show different tendencies when separated by IA rupture status. Serum cholesterol shows an important association with rupture of aneurysm $(p=0.0382)$. High cholesterol and use of statins show a tendency for worse outcome with ruptured aneurysm, and the opposite is true for unruptured aneurysm. The presence of atherosclerotic plaques was not related with worse outcomes.
\end{abstract}

received

June 20, 2021

accepted after revision

September 6, 2021

published online

January 6, 2022

Jangry 6, 2022

DOI https://doi.org/

10.1055/s-0041-1741419. ISSN 0103-5355.

\footnotetext{
(c) 2022. Sociedade Brasileira de Neurocirurgia. All rights reserved. This is an open access article published by Thieme under the terms of the Creative Commons Attribution-NonDerivative-NonCommercial-License, permitting copying and reproduction so long as the original work is given appropriate credit. Contents may not be used for commercial purposes, or adapted, remixed, transformed or built upon. (https://creativecommons.org/ licenses/by-nc-nd/4.0/) Thieme Revinter Publicações Ltda., Rua do Matoso 170, Rio de Janeiro, RJ, CEP 20270-135, Brazil
} 


\section{Resumo}

Palavras-chave
- colesterol
- estatinas
- placa
- desfechos para Al

Conclusions Multiple and opposite mechanisms might be involved in the pathophysiology of IA. Ruptured aneurysms are associated with higher levels of serum cholesterol. Serum cholesterol and statins use were not correlated with worse outcomes, but further studies are important to clarify these relationships.

Introdução Aneurisma intracranial (Al) é uma grande preocupação para a saúde. Evidências apontam que o uso de estatina para reduzir o colesterol sérico diminui o risco cardiovascular em diversas doenças, mas o impacto em Al ainda não foi descrito. Este estudo almeja determinar se o uso de estatina e o nível sérico de colesterol interferem no desfecho clínico após a ocorrência de Als.

Métodos Uma coorte de pacientes com Al foi analisada. Os dados sociodemográficos dos pacientes foram coletados. Ao final de 6 meses de acompanhamento, aplicou-se a escala modificada de Rankin (mRS). Os dados sobre uso de estatina, existência de placa aterosclerótica em imagens radiológicas, e colesterol sérico de 35 pacientes foram incluídos no estudo. Modelos de regressão linear foram usados para determinar a influência dessas 6 variáveis nos desfechos clínicos.

Resultados A prevalência de placa aterosclerótica, colesterol elevado, e uso de estatina foram respectivamente $34,3 \%, 48,5 \%$ e $14,2 \%$. Estatina e colesterol sérico não impactaram nos desfechos medidos pela mRS em 6 meses $(p>0,05)$, mas mostraram diferentes tendências quando separados pelo estado de ruptura do Al. Colesterol sérico apresenta uma importante associação com ruptura de aneurisma $(p=0,0382)$. Colesterol elevado e uso de estatinas representam uma tendência a piores desfechos para aneurismas rompidos, e o oposto é verdade para os não rompidos. A presença de placa aterosclerótica não está relacionada com piores resultados.

Conclusões Mecanismos múltiplos e opostos podem estar envolvidos na patofisiologia do Al. Aneurismas rompidos estão associados com maiores níveis de colesterol sérico. Colesterol sérico e estatinas não foram correlacionados com piores desfechos, mas mais estudos são importantes para clarificar a relação entre esses fatores.

\section{Introduction}

Intracranial aneurysm (IA) is a major healthcare concern. It is defined as a dilation of a cerebral blood vessel. Aneurysms are considered as the consequence of an abnormal blood flow. Increased hemodynamic stress leads to vessel damage and subsequent inflammation. ${ }^{1}$ The inflammatory process can be harmful to the vessel, leading to apoptosis of its smooth muscle cells and to progressive weakening of the vessel, as they are the primary matrix-synthesizing cells in the vessel. ${ }^{1}$

The lesions are widely spread in the adult population. Some studies suggest that the prevalence of IA among this group can reach up to $5 \%{ }^{2}$ Clinical prognosis can vary widely depending on the size of the lesion. ${ }^{3,4}$ Subarachnoid hemorrhage (SAH) is a major complication, occurring in about 6 to 7 persons annually, $85 \%$ of which can be directly attributed to aneurysm rupture. ${ }^{5}$ Almost $2 / 3$ of patients end up with a poor outcome such as death, or permanent disabilities. ${ }^{6}$ The case fatality after SAH can reach up to $50 \%$ and even though it is more likely to happen in older people, half of the patients are under 55 years. $^{5}$
Many attempts have been made to predict patient outcome after SAH with mixed results. Most studies use a combination of methods, including versions of the modified Rankin scale (mRS) ${ }^{7}$ and Glasgow outcome scale (GOS), ${ }^{8}$ as well as variables such as the patient's gender, age, history and aneurysm size and location. ${ }^{7}$ The lack of consistency and precision in the methods used casts doubt on their ability to predict outcomes reliably. ${ }^{9} \mathrm{~A}$ prime concern among patients with IA is arterial embolism; thromboembolisms occur when atherosclerotic plaques have their lipidic core exposed to the bloodstream. ${ }^{9}$ Large thrombotic occlusions can happen either in the anterior or posterior intracranial circulation, resulting in cortical symptoms, as well as medullary and pontine infarction syndromes, respectively. ${ }^{10}$ Atherosclerotic lesions are relatively common in patients with IA, with one study finding some visible atherosclerotic alterations in $37 \%$ of the patients during operations. ${ }^{11}$

The formation and progression of atherosclerotic plaques is a multifactorial process, but one key contributor to it is the low-density lipoprotein cholesterol (LDL). When deposited in the vessel's wall, LDL oxidizes, attracting monocyte-derived 
cells to the lesion's site. Those cells penetrate the vessel wall due to its reduced integrity, reaching the sub endothelial space where they will differentiate into mature macrophages. Those macrophages will eventually internalize the lipoproteins to form the foam cells and the plaque. ${ }^{12,13}$ Therefore, it stands to reason that the inhibition of $L D L$ synthesis could prove to be an effective way of preventing strokes. Some of the major drugs capable of affecting LDL synthesis are statins, competitive inhibitors of HMG-CoA reductase that end up inhibiting overall lipoprotein synthesis in the liver and, consequentially, LDL production. ${ }^{14}$ Additionally, it has been found that statin increases the high-density lipoproteins (HDL), ${ }^{15}$ which have been linked with atherosclerotic plaque regression. ${ }^{16}$

Cholesterol levels have also shown association with other vascular diseases; ${ }^{17}$ and while lower levels of LDL and higher levels of HDL are associated with the prevention of atherosclerotic plaque formation, the opposite is true regarding the prevention of $\mathrm{SAH},{ }^{18}$ making the role of statin in IA even more unclear.

As there is evidence to support the efficacy of statin in the prevention of strokes, ${ }^{19}$ this study aims to investigate the possible correlation between statins, serum cholesterol levels and outcome for IAs after 6 months.

\section{Methods}

\section{Study Design}

This is a prospective single-center cohort study with patients who were admitted in the hospital due to SAH, between January 2018 and November 2019. All patients were treated with either microsurgery or embolization. Social and demographic data were acquired from charts of patients from the department of neurosurgery of the Hospital das Clínicas
(HCFMUSP) database. It was also collected information about statins use, high cholesterol levels, presence of atherosclerotic plaques with radiological image, and aneurysm intracranial rupture status upon admission. The mRS scores were collected prospectively at 6 months of follow-up.

\section{Population Data}

The study recruited 401 patients (adult men and women) from the Department of Neurological Surgery of the Hospital das Clínicas da FMUSP (HCFMUSP). After admission, the patients were divided in two groups: the first included patients with SAH and ruptured aneurysm (244), and the second included patients with unruptured aneurysms undergoing elective surgery (177).

Data from 401 patients were analyzed, and 35 were included in this study (-Fig. 1). All 35 patients with data for serum cholesterol, use of statins, and presence or not of atherosclerotic plaque were followed for 6 months for outcome evaluation.

A questionnaire concerning previous risk factors to aneurysmatic disease was performed, which included hypertension, smoking, alcoholism, drug abuse, family history, previous SAH and date of the last event. Besides that, a socioeconomic evaluation of the participants was performed, assessing: educational level, family income, occupation, and marital status. Patients were followed for 6 months. At the end of the study, mRS and GOS were used to measure outcome after SAH.

\section{Exclusion Criteria}

Patients with missing cholesterol and statins use data, radiological images for atherosclerotic plaques status, or who stopped attending the follow-up appointments in less than 6 months were excluded from the study.
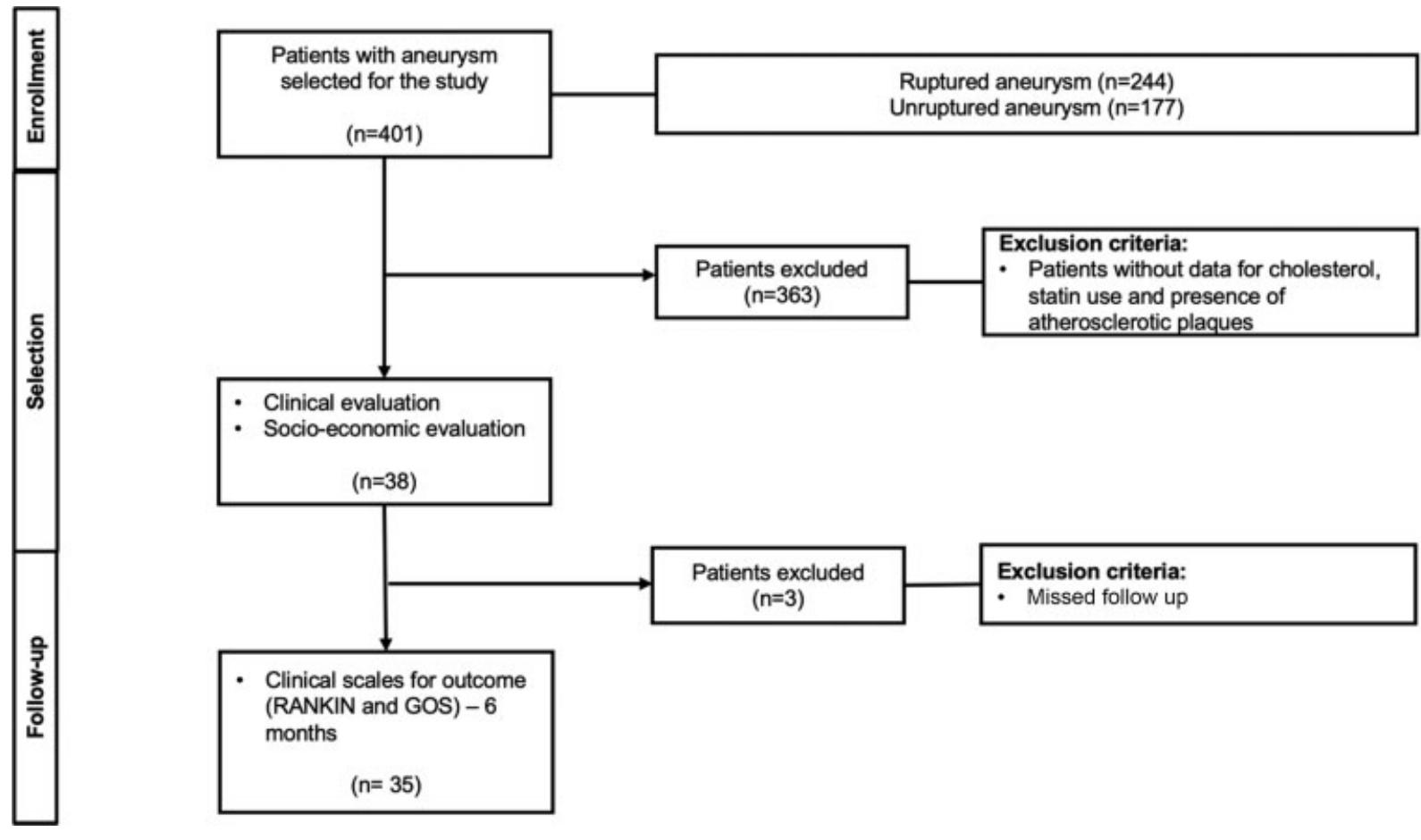

Fig. 1 Population data and selection process based on inclusion and exclusion criteria. Thirty-five patients were included in this study. 


\section{Inclusion Criteria}

All patients were included, regardless of gender and age, with ruptured and unruptured brain aneurysms who were admitted to HCFMUSP between January 2018 and November 2019. Patients with high-grade SAH, rated 4 or 5 in the Hunt Hess scale, were not included.

\section{Statistical Analysis}

We used univariate linear and logistic regressions with statin use, presence of atherosclerotic plaques, and high cholesterol as independent and dichotomous variables. High cholesterol was defined as a serum cholesterol higher than $200 \mathrm{mg} / \mathrm{dl}$. Serum cholesterol at admission was also used as an independent and continuous variable. The outcome was mRS at 6 -months. Significance level was established as 0.05 . For the logistic regression, unfavorable outcome was defined as $\mathrm{mRS}$ score greater than 2 .

Patients were also divided in ruptured and unruptured aneurysm groups. The prevalence of statin use between the groups was analyzed with Fisher exact test for categorical data. A significance level of 0.05 was used.

\section{Results}

\section{Epidemiology and Comorbidities}

Among the 35 patients included in the study, the average age was $57.71 \pm 9.79$ years, and $91.4 \%$ were male. Hypertension was present in $62.9 \%$ of the patients, $22.9 \%$ had previous diabetes mellitus, $37.1 \%$ were smokers, $14.3 \%$ were heavy alcohol drinkers and $42.9 \%$ patients had ruptured aneurysm. ( - Table 1). Regarding treatment, $6 \%$ were treated with embolization and 93\% with microsurgery. No patients had previous history of ruptured aneurysms.

\section{Serum Cholesterol and Outcome}

The median Glasgow coma scale (GCS) at admission in the hospital was 14.

The mean value of serum cholesterol in the group with unruptured aneurysm was 195.2, and in the ruptured aneurysm group was 211.6. This difference was not statistically significant $(p>0.05)$. The mRS score at 6 months was on average $1.4 \pm 0.91$. The mean serum cholesterol upon admission was $202.25 \pm 46.28$ ( - Fig. 2). A total of 17 patients had cholesterol levels higher than $200 \mathrm{mg} / \mathrm{dl}$, with $52,9 \%$ being in the ruptured aneurysm group.

The linear regression using cholesterol as a predictor and the mRS score at 6 months shows that cholesterol does not have a statistically significant influence in the outcome measured by the mRS $(p>0.05)$. However, adding an interaction term for serum cholesterol and rupture of aneurysm, the linear regression model shows that these two variables are influenced by one another $(p=0.0382)$.

Despite the fact serum cholesterol itself does not show a significant influence, high cholesterol shows a tendency for

Table 1 Patient characteristics

\begin{tabular}{|l|l|l|l|l|}
\hline Intracranial aneurysm & Unruptured (20) & Ruptured (15) & $p$-value \\
\hline Epidemiology & & & & \\
\hline & Age (years) & $60.8(8.14)$ & $53.73(10.61)$ & 0.04 \\
\hline & Gender (male) & $18(90 \%)$ & $14(93.3 \%)$ & 1.00 \\
\hline & Hypertension & $12(60 \%)$ & $10(66.7 \%)$ & 0.74 \\
\hline & Diabetes mellitus & $4(20 \%)$ & $4(26.7 \%)$ & 0.70 \\
\hline & Smoking & $5(25 \%)$ & $8(53.3 \%)$ & 0.16 \\
\hline & Alcoholism & $2(10 \%)$ & $3(20 \%)$ & 0.63 \\
\hline & Previous SAH & 0 & 0 & - \\
\hline & Multiple aneurysm & $7(100 \%)$ & $5(35.7 \%)$ & 0.01 \\
\hline & & & & \\
\hline & Hunt Hess - admission & - & $2.5(1.23)$ & - \\
\hline & WFNS - admission & - & $2(1.29)$ & - \\
\hline & GSC - admission & - & $13(3.06)$ & - \\
\hline & GOS - 6 months & $4.75(0.64)$ & $4.8(0.41)$ & 0.78 \\
\hline & mRS - 6 months & $1.4(1.0)$ & $1.4(0.83)$ & 1.00 \\
\hline & & & & $211.6(53.2)$ \\
\hline & Serum cholesterol (mg/dL) & $195.2(40.2)$ & $5(33.3 \%)$ & 0.33 \\
\hline & Atherosclerotic plaque & $7(35 \%)$ & $1(6.7 \%)$ & 1.00 \\
\hline & Statins & $4(20 \%)$ & 0.37 \\
\hline
\end{tabular}

Abbreviations: GOS, Glasgow outcome scale; GCS, Glasgow coma scale; mRS, modified Rankin scale; SAH, subarachnoid hemorrhage. Data is presented as mean (SD) for continuous variables, and count (\%) for categorical variables. Patients were divided in ruptured and unruptured aneurysm. P-value shows comparison between groups. 


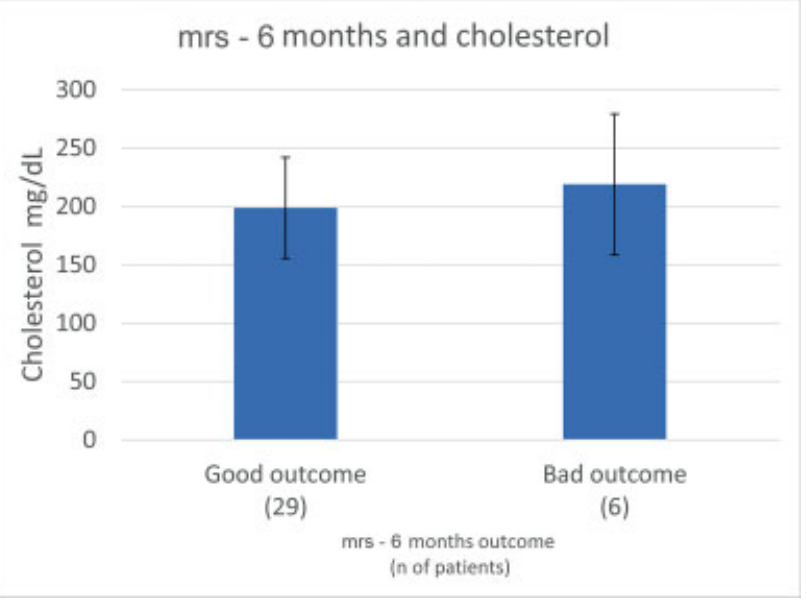

Fig. 2 Patients' admission cholesterol and mRS scale at 6 months. Unfavorable outcome was defined as mRS score greater than 2. Favorable outcome was defined as a score lower or equal to 2.

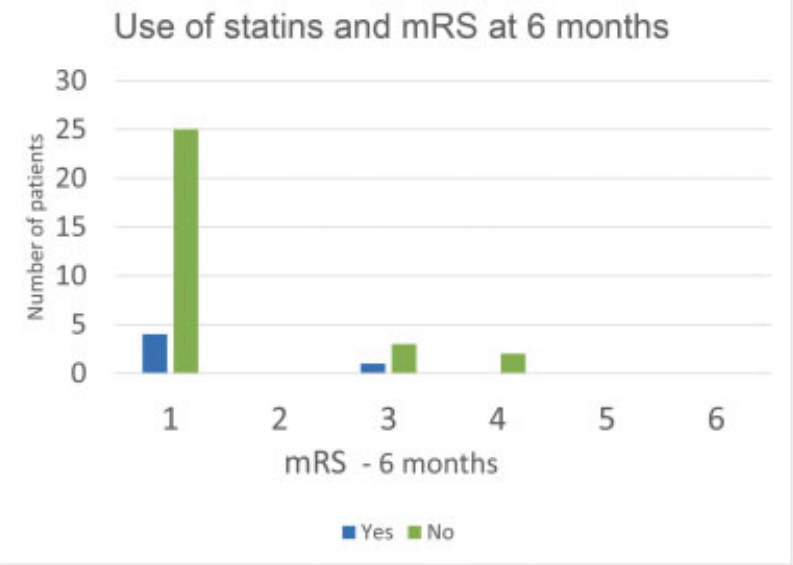

Fig. 3 Distribution of mRS - 6 months for outcome evaluation based on statins use. worse outcomes in the ruptured aneurysm group (0.76 increase in mRS score for every $100 \mathrm{mg} / \mathrm{dl}$ increase in serum cholesterol $[-0.05 ; 1.57], p=0.064)$, but a tendency for better outcomes in the unruptured aneurysm group $(-0.705 \mathrm{mRS}$ score decrease for every $100 \mathrm{mg} / \mathrm{dl}$ increase in serum cholesterol $[-1.87 ; 0.46], p=0.223)$.

\section{Statin and Outcome}

In the unruptured aneurysm group, 20\% were using statins. In the ruptured aneurysm group, only $6.7 \%$ were using this medication. This difference was not statistically significant $(p>0.05)$ (-Fig. 3).

The linear regression with "use of statins" as a predictor and the mRS scale score at 6-months shows that statins does not have a statistically significant influence in the outcome measured by the mRS ( $p>0.05)$.

The sub analyses with ruptured and unruptured aneurysm show no difference in either group $(p>0.05)$. However, while patients using statins had a tendency for worse outcomes in unruptured aneurysm ( 0.125 increase in the $\mathrm{mRS}$ at 6 months [-1.07; 1.32]), statin use was correlated with better outcomes in ruptured aneurysm (-0.429 decrease in the mRS at 6 months $[-2.33 ; 147]$.$) (-Table 2$ ).

\section{Atherosclerotic Plaques and Outcome}

In the unruptured aneurysm group, $35.0 \%$ had atherosclerotic plaques. In the ruptured aneurysm group, only $33.3 \%$ presented atherosclerotic plaques. This difference was not statistically significant ( $p>0.05)$.

All atherosclerotic plaques were directly correlated with the aneurysm's site, with 11 cases (32.3\%) being in the posterior communicating artery, 10 (29.4\%) in the middle cerebral artery, $6(17.6 \%)$ in the anterior communicating artery, 5 (14.7\%) in the internal carotid artery and 2 (5.8\%) cases in the anterior cerebral artery.

Table 2 Linear regression model for prediction of outcome 6 months after intracranial aneurysm event

\begin{tabular}{|c|c|c|c|c|}
\hline \multicolumn{5}{|l|}{ Simple linear regression } \\
\hline \multirow[t]{2}{*}{ Coefficients for univariate analyses: } & \multicolumn{2}{|l|}{ Ruptured } & \multicolumn{2}{|c|}{ Unruptured } \\
\hline & Estimate & $p$-value & Estimate & $p$-value \\
\hline Atherosclerotic plaques & 0.0 & 1.0 & -0.176 & 0.717 \\
\hline Cholesterol & 0.760 & 0.064 & -0.705 & 0.223 \\
\hline Statins & -0.429 & 0.635 & 0.125 & 0.829 \\
\hline \multicolumn{5}{|l|}{ Multiple linear regression } \\
\hline Coefficients for multivariate analyses: & \multicolumn{2}{|l|}{ Estimate } & \multicolumn{2}{|l|}{$p$-value } \\
\hline Intercept & \multicolumn{2}{|l|}{2.785} & \multicolumn{2}{|l|}{-} \\
\hline Atherosclerotic plaques & \multicolumn{2}{|l|}{-0.031} & \multicolumn{2}{|l|}{0.927} \\
\hline Cholesterol & \multicolumn{2}{|l|}{-0.700} & \multicolumn{2}{|l|}{0.194} \\
\hline Statins & \multicolumn{2}{|l|}{-0.041} & \multicolumn{2}{|l|}{0.930} \\
\hline Rupture & \multicolumn{2}{|l|}{-2.982} & \multicolumn{2}{|l|}{0.051} \\
\hline Interaction (rupture: cholesterol) & \multicolumn{2}{|l|}{0.015} & \multicolumn{2}{|l|}{$0.047^{*}$} \\
\hline
\end{tabular}

Serum cholesterol, use of statins, and presence of atherosclerotic plaque were used as independent variables. Multiple linear regression scale measured at 6 months was defined as outcome. 


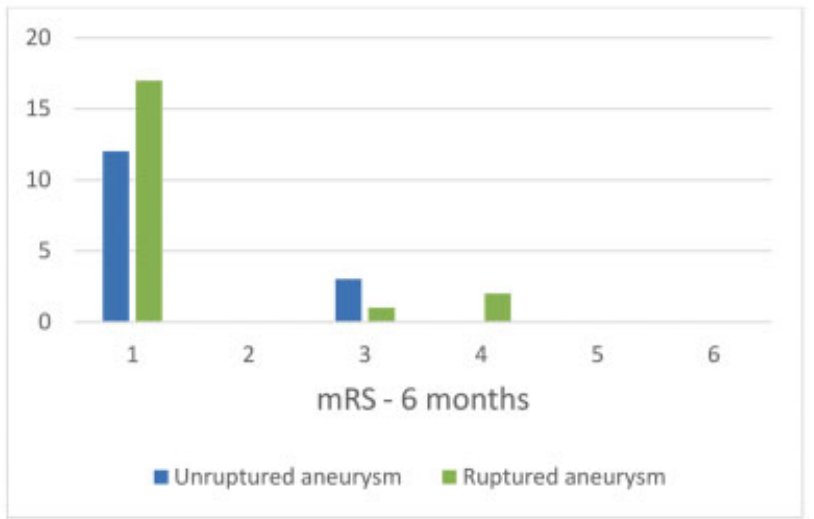

Fig. 4 Distribution of ruptured and unruptured aneurysm based on outcome measured by mRS scale -6 months.

The linear regression with "presence of atherosclerotic plaque" as a predictor and the mRS score at 6-months shows that atherosclerotic plaques do not have a statistically significant influence in the outcome measured by the mRS $(p>0.05)$.

The sub analyses with ruptured and unruptured aneurysm show no differences in either group $(p>0.05)$. There was also no statistically significant difference in the distribution of ruptured and unruptured aneurysm based on the mRS at 6 months $(p>0.05)$ ( - Fig. 4).

\section{Discussion}

There are many ways already used to predict IA outcome. The World Federation of Neurological Surgeons' (WFNS) Grading System for Subarachnoid Hemorrhage scale correlates lack of ruptured aneurysm and higher levels of consciousness with better outcomes. ${ }^{20,21}$ Further research seems to indicate that advanced age and larger aneurysms contribute to worse outcomes. ${ }^{22}$ Notably, cholesterol levels and the presence of atherosclerotic plaques are absent from these scales, despite being so intertwined with the disease's pathophysiology that it would not be unreasonable to think they may have some impact in its outcome.

The serum cholesterol level may be absent from most outcome predictors, but we can find it somewhat indirectly in statin research. The role of statins as a preventive factor in IA remains ambiguous in the literature. In some animal models it has been found that they could either halt ${ }^{23}$ or promote $^{24}$ IA progression. In clinical studies however, no correlation was found between statin use and IA prevention, ${ }^{25}$ aligning with our findings.

Even though the biochemical role of statins in reducing the inflammatory processes in the vessels walls is largely understood, it doesn't seem to correlate with actual clinical studies when it comes to IA prevention. The inflammatory process in the vessel where macrophages turn into foam cells and form plaques can be attributed to LDL, as its oxidized form is incorporated into these cells. ${ }^{26}$ The oxidized LDL induces the vessel's endothelium to express certain molecules that allow monocytes to adhere and infiltrate the vessel. ${ }^{27}$ Because statins reduce $\mathrm{LDL}^{15}$ and oxidized $\mathrm{LDL}^{28}$ levels, the logical conclusion would be that they should be beneficial to prevent intracranial aneurysms. Since this assertion is not verified by clinical trials, inflammation does not fully explain the underlying causes of IAs, and other factors are probably at play.

Despite the lack of statistical significance in our study regarding the tendency of higher levels of cholesterol to correlate with worse outcomes, other studies could verify this relation. ${ }^{28,29}$ Measuring cholesterol as a whole might be problematic when it comes to outcome. Systematic reviews and meta analyses ${ }^{18}$ show that even though hemorrhagic strokes are negatively correlated with total cholesterol levels, only a higher level of HDL is positively associated with hemorrhagic strokes, LDL being the opposite. ${ }^{18}$

One possible reason for this phenomenon would be that low levels of cholesterol could promote necrosis in the arterial medial layer's smooth muscle cells, ${ }^{30,31}$ making the vessel more likely to suffer microaneurysms. ${ }^{32}$ Another theory claims that low cholesterol may reduce platelet aggregability, thus making hemorrhage more likely. ${ }^{30,33}$ This might explain why we couldn't find a correlation between statin use and better outcomes, as it primarily reduces LDL levels and the increased likelihood for hemorrhagic stroke may mitigate their benefits. It is important to note that statin therapy was not associated with increased risks of hemorrhage. ${ }^{34-38}$

It has already been established that atherosclerosis is the underlying pathological basis of strokes, coronary artery disease, peripheral artery disease, and hipertension. ${ }^{39-42}$ However, being the cause of the disease does not necessarily mean that the maintenance of cholesterol levels are the main contributors to negative outcomes. As a matter of fact, high cholesterol is only the sixth risk factor regarding attributable deaths in heart attacks and strokes. ${ }^{42}$ Furthermore, literature is scarce when it comes to IA specifically, making it hard to determine if the maintenance of cholesterol levels is as important in intracranial aneurysms as it is in other cardiovascular diseases. ${ }^{43,44}$ Despite the fact that our results could not establish any significant change regarding presence or not of atherosclerotic plaques and clinical outcomes, more research is required in the subject.

The relatively small number of patients with concomitant data for statin use, serum cholesterol level and presence of atherosclerotic plaque, might explain the lack of statistical significance for some variables in our study. Moreover, a clinical trial with randomization of treatment with statins and a longitudinal control of serum cholesterol levels is also necessary for a definitive answer. Other limitations include the lack of a model with more variables that affect IA outcomes, and data for use of different types of statin and their dose, which may interfere with results.

Patients with major complications of IA have notably poor outcomes, ${ }^{45,46}$ making accurate prediction a valuable tool in the decision making process of the treatment. ${ }^{47}$ Current prediction methods can be helpful to define probable outcome, but they are not always accurate nor widely used. ${ }^{45-48}$ Even though we could not find a correlation between 
cholesterol levels and outcome, the investigation of other pathophysiological components of IA may prove helpful in determining a more accurate outcome.

\section{Conclusion}

Intracranial aneurysm is an important healthcare problem, and understating the factors that might have an influence in the outcome of IA is the key for an adequate treatment. Our results show that there is no statistical significance to prove that use of statins, serum cholesterol and the presence of atherosclerotic plaque correlate with worse outcomes, even though ruptured aneurysms were associated with higher levels of serum cholesterol. Multiple and opposite mechanisms might be involved in the circumstance of IA and further studies are needed to describe and understand the pathophysiology specific for IA.

\section{Ethical Standards}

This research project was approved by the Ethics and Research Committee of the Hospital das Clínicas of the FMUSP. Online registration CAPPesq: 15226. Approved 06/20/2016. Approved on the Brazilian platform CAAE, number: 61719416.6.0000.0068

\section{Conflict of Interests}

The authors have no conflict of interests to declare.

\section{References}

1 Chalouhi N, Hoh BL, Hasan D. Review of cerebral aneurysm formation, growth, and rupture. Stroke 2013;44(12):3613-3622

2 Kaut Roth C, Faulkner WH. Review Questions for MRI. Rev Quest MRI; 2013:928-939

3 Malhotra A, Wu X, Forman HP, Grossetta NardiniHK, Matouk CC, Gandhi D, Moore C, Sanelli P. Growth and Rupture Risk of Small Unruptured Intracranial Aneurysms: A Systematic Review. Ann Intern Med 2017 Jul 4;167(1):26-33. doi: 10.7326/M17-0246. Epub 2017 Jun 6. Erratum in: Ann Intern Med. 2018 Dec 4;169 (11):824. PMID: 28586893

4 Wiebers DO, Whisnant JP, Huston J III, et al; International Study of Unruptured Intracranial Aneurysms Investigators. Unruptured intracranial aneurysms: natural history, clinical outcome, and risks of surgical and endovascular treatment. Lancet 2003;362 (9378):103-110

5 van Gijn J, Kerr RS, Rinkel GJ. Subarachnoid haemorrhage. Lancet 2007;369(9558):306-318

6 Hop JW, Rinkel GJ, Algra A, van Gijn J. Case-fatality rates and functional outcome after subarachnoid hemorrhage: a systematic review. Stroke 1997;28(03):660-664

7 Wiebers DO, Whisnant JP, Sundt TM Jr, O'Fallon WM. The significance of unruptured intracranial saccular aneurysms. J Neurosurg 1987;66(01):23-29

8 Jennett B, Bond M. Assessment of outcome after severe brain damage. Lancet 1975 Mar 1;1(7905):480-4. doi: 10.1016/s01406736(75)92830-5. PMID: 46957

9 Campbell BCV, De Silva DA, Macleod MR, et al. Ischaemic stroke. Nat Rev Dis PrimSpringer US2019:5

$10 \mathrm{Kim}$ JS, Caplan LR. Clinical Stroke Syndromes. Front Neurol Neurosci 2016;40:72-92

11 Frösen J, Tulamo R, Heikura T, et al. Lipid accumulation, lipid oxidation, and low plasma levels of acquired antibodies against oxidized lipids associate with degeneration and rupture of the intracranial aneurysm wall. Acta Neuropathol Commun 2013; $1: 71$

$12 \mathrm{Yu}$ XH, Fu YC, Zhang DW, Yin K, Tang CK. Foam cells in atherosclerosis. Clin Chim Acta 2013 Sep 23;424:245-52. doi: 10.1016/j. cca.2013.06.006. Epub 2013 Jun 16. PMID: 23782937

13 Jickling GC, Liu D, Ander BP, Stamova B, Zhan X, Sharp FR. Targeting neutrophils in ischemic stroke: translational insights from experimental studies. J Cereb Blood Flow Metab 2015 Jun;35 (6):888-901. doi: 10.1038/jcbfm.2015.45. Epub 2015 Mar 25. PMID: 25806703; PMCID: PMC4640255

14 Wiggers CJ. Willem EINTHOVEN (1860-1927). Some facets of his life and work. Circ Res 1961 Mar;9:225-234. Doi: 10.1161/01. res.9.2.225. PMID: 13785174

15 McTaggart F, Jones P. Effects of statins on high-density lipoproteins: a potential contribution to cardiovascular benefit. Cardiovasc Drugs Ther 2008;22(04):321-338

16 Di Bartolo BA, Psaltis PJ, Bursill CA, Nicholls SJ. Translating Evidence of HDL and Plaque Regression. Arterioscler Thromb Vasc Biol 2018;38(09):1961-1968

17 Lewington S, Whitlock G, Clarke R, et al; Prospective Studies Collaboration. Blood cholesterol and vascular mortality by age, sex, and blood pressure: a meta-analysis of individual data from 61 prospective studies with 55,000 vascular deaths. Lancet 2007; 370(9602):1829-1839

18 Wang X, Dong Y, Qi X, Huang C, Hou L. Cholesterol levels and risk of hemorrhagic stroke: a systematic review and meta-analysis. Stroke 2013;44(07):1833-1839

19 Christophe B, Karatela M, Sanchez J, Pucci J, Connolly ES. Statin Therapy in Christophe B, Karatela M, Sanchez J, Pucci J, Connolly ES. Statin Therapy in Ischemic Stroke Models: A Meta-Analysis. Transl Stroke Res 2020 Aug;11(4):590-600. doi: 10.1007/s12975019-00750-7. Epub 2019 Dec 2. PMID: 31788761

20 Wilson JTL, Hareendran A, Hendry A, Potter J, Bone I, Muir KW. Reliability of the modified Rankin Scale across multiple raters: benefits of a structured interview. Stroke 2005;36(04): 777-781

21 Teasdale GM, Drake CG, Hunt W, et al. A universal subarachnoid hemorrhage scale: report of a committee of the World Federation of Neurosurgical Societies. J Neurol Neurosurg Psychiatry 1988; 51(11): 1457

22 Platz J, Güresir E, Schuss P, Konczalla J, Seifert V, Vatter H. The impact of the body mass index on outcome after subarachnoid hemorrhage: is there an obesity paradox in $\mathrm{SAH}$ ? A retrospective analysis. Neurosurgery 2013;73(02):201-208

23 Aoki T, Kataoka H, Ishibashi R, Nozaki K, Hashimoto N. Simvastatin suppresses the progression of experimentally induced cerebral aneurysms in rats. Stroke 2008;39(04):1276-1285

24 Tada Y, Kitazato KT, Yagi K, et al. Statins promote the growth of experimentally induced cerebral aneurysms in estrogen-deficient rats. Stroke 2011;42(08):2286-2293

25 Marbacher S, Schläppi JA, Fung C, Hüsler J, Beck J, Raabe A. Do statins reduce the risk of aneurysm development? A case-control study. J Neurosurg 2012 Mar;116(3):638-42. doi: 10.3171/ 2011.10.JNS11153. Epub 2011 Nov 25. PMID: 22117185

26 Schwartz CJ, Valente AJ, Sprague EA, Kelley JL, Cayatte AJ, Mowery J. Atherosclerosis. Potential targets for stabilization and regression. Circulation 1992;86(6, Suppl)III117-III123

27 Mertens A, Holvoet P. Oxidized LDL and HDL: antagonists in atherothrombosis. FASEB J 2001;15(12):2073-2084

28 He L, Xu R, Wang J, Zhang L, Zhang L, Zhao W, Dong W. Prestroke statins use reduces oxidized low density lipoprotein levels and improves clinical outcomes in patients with atrial fibrillation related acute ischemic stroke. BMC Neurol 2019 Oct 18;19 (1):240. doi: 10.1186/s12883-019-1463-7. PMID: 31627722; PMCID: PMC6800490

29 Lindbohm JV, Kaprio J, Korja M. Cholesterol as a risk factor for subarachnoid hemorrhage: A systematic review. PLoS One 2016; 11(04):e0152568 
50 Cholesterol, Statins, and Plaques: Outcomes for IA Pipek et al.

30 Tirschwell DL, Smith NL, Heckbert SR, Lemaitre RN, Longstreth WT Jr, Psaty BM. Association of cholesterol with stroke risk varies in stroke subtypes and patient subgroups. Neurology 2004;63 (10):1868-1875

31 Ooneda G, Yoshida Y, Suzuki K, et al. Smooth muscle cells in the development of plasmatic arterionecrosis, arteriosclerosis, and arterial contraction. Blood Vessels 1978;15(1-3):148-156

32 Konishi M, Iso $\mathrm{H}$, Komachi $\mathrm{Y}$, et al. Associations of serum total cholesterol, different types of stroke, and stenosis distribution of cerebral arteries. The Akita Pathology Study. Stroke 1993;24(07): 954-964

33 Tandon N, Harmon JT, Rodbard D, Jamieson GA. Thrombin receptors define responsiveness of cholesterol-modified platelets. J Biol Chem 1983;258(19):11840-11845

34 Heart Protection Study Collaborative Group. MRC/BHF Heart Protection Study of cholesterol lowering with simvastatin in 20,536 high-risk individuals: a randomised placebo-controlled trial. Lancet 2002;360(9326):7-22

35 Byington RP, Davis BR, Plehn JF, et al. Reduction of stroke events with pravastatin: the Prospective Pravastatin Pooling (PPP) Project. Circulation 2001;103(03):387-392

36 McKinney JS, Kostis WJ. Statin therapy and the risk of intracerebral hemorrhage: a meta-analysis of 31 randomized controlled trials. Stroke 2012;43(08):2149-2156

37 Hackam DG, Woodward M, Newby LK, et al. Statins and intracerebral hemorrhage: collaborative systematic review and metaanalysis. Circulation 2011;124(20):2233-2242

38 Amarenco P, Labreuche J. Lipid management in the prevention of stroke: review and updated meta-analysis of statins for stroke prevention. Lancet Neurol 2009;8(05):453-463

39 Moneta GL. Aortic Arch Plaques and Risk of Recurrent Stroke and Death. Yearb Vasc Surg Elsevier Ltd; 2010:251-253
40 French Study of Aortic Plaques in Stroke Group Amarenco P, Cohen A, Hommel M, Moulin T, Leys D, Bousser M-G. Atherosclerotic disease of the aortic arch as a risk factor for recurrent ischemic stroke. N Engl J Med 1996 May 9;334(19):1216-21. doi: 10.1056/ NEJM199605093341902. PMID: 8606716

41 Esenwa C, Gutierrez J. Secondary stroke prevention: challenges and solutions. Vasc Health Risk Manag 2015;11:437-450

42 Thomas H, Diamond J, Vieco A, et al. Global Atlas of Cardiovascular Disease 2000-2016: The Path to Prevention and Control. Glob Heart 2018;13(03):143-163

43 Chou R, Dana T, Blazina I, Daeges M, Jeanne TL. Statins for Prevention of Cardiovascular Disease in Adults: Evidence Report and Systematic Review for the US Preventive Services Task Force. JAMA 2016;316(19):2008-2024

44 Lowe RN, Vande Griend JP, Saseen JJ. Statins for the primary prevention of cardiovascular disease in the elderly. Consult Pharm 2015;30(01):20-30

45 Zhao B, Tan X, Zhao Y, et al. Variation in patient characteristics and outcomes between early and delayed surgery in poor-grade aneurysmal subarachnoid hemorrhage. Neurosurgery 2016;78(02):224-231

46 Huang APH, Arora S, Wintermark M, Ko N, Tu YK, Lawton MT. Perfusion computed tomographic imaging and surgical selection with patients after poor-grade aneurysmal subarachnoid hemorrhage. Neurosurgery 2010;67(04):964-974, discussion 975

47 Howard BM, Barrow DL. Outcomes for Patients with Poor-Grade Subarachnoid Hemorrhage: To Treat or Not To Treat? World Neurosurg 2016;86:30-32

48 van Donkelaar CE, Bakker NA, Birks J, Veeger NJGM, Metzemaekers JDM, Molyneux AJ, Groen RJM, van Dijk JMC. Prediction of Outcome After Aneurysmal Subarachnoid Hemorrhage. Stroke 2019 Apr;50(4):837-844. doi: 10.1161/STROKEAHA.118.023902. PMID: 30869562 